\title{
Evaluation of a latex agglutination test using particles coated with crude exoantigen of Paracoccidioides brasiliensis in the serodiagnosis of paracoccidioidomycosis
}

Avaliação do teste de aglutinação com partículas de látex sensibilizadas com exoantígeno bruto de Paracoccidioides brasiliensis no sorodiagnóstico da paracoccidioidomicose

Evaluación de la prueba de aglutinación con partículas de látex sensibilizadas con exoantígeno bruto de Paracoccidioides brasiliensis en el serodiagnóstico de la paracoccidioidomicosis

Fabíola Silveira Gomes

Universidade Federal do Pará, Belém, Pará, Brasil

Laboratório de Micologia, Seção de Bacteriologia e Micologia, Instituto

Evandro Chagas/SVS/MS, Ananindeva, Pará, Brasil
Silvia Helena Marques-da-Silva

Laboratório de Micologia, Seção de Bacteriologia e Micologia, Instituto Evandro Chagas/SVS/MS, Ananindeua, Pará, Brasil

Introduction: Paracoccidioidomycosis (PCM) is a fungal disease caused by the dimorphic agent, P. brasiliensis and is a significant pulmonary mycosis in Latin American countries such as Venezuela, Argentina, and Brazil. The disease commonly manifests as a pulmonary chronic infection with extra-pulmonary lesions, such as those of the oral mucosa. The route of infection for $P$. brasiliensis is the inhalation of infectious propagules that have developed from the mycelium form of the fungus $\left(25^{\circ}\right)$, and these can convert to the yeast form in the lungs $\left(35^{\circ} / 37^{\circ}\right)$. Patients can present with one of following two clinical forms: the acute clinical form (subacute/juvenile type) or the chronic form (adult type). A definitive diagnosis is made by the visualization or the isolation of the fungus from sputum or bronchoalveolar lavage specimens from patients. As the conventional diagnostic tools are time-consuming and lack the sensitivity of conventional diagnoses, the detection of antibodies from serological assays can also be an effective tool for diagnosis and to monitor the response to treatment. Moreover, the latex agglutination test (LA test) has advantages over these diagnostic tools, such as its rapid execution, and this study demonstrates its effectiveness as a diagnostic test for the serodiagnosis of PCM. Objective: The aim of present study was to determine the ability of the LA test to detect antibodies in the sera of PCM patients. Materials And Methods: Solutions of $1 \%$ latex particles (LA) in $\mathrm{CO}_{3}{ }^{2} / \mathrm{HCO}_{3}$ buffer at $\mathrm{pH} 9.2$ were coated with $400 \mu \mathrm{g}$ crude exoantigen from the yeast form of $P$. brasiliensis. In the dark, $25 \mu \mathrm{L}$ of serum from glass slides was homogenized with $25 \mu \mathrm{L}$ of $\mathrm{LA}$ test solution (diluted 1:2 in the same buffer) and incubated for 5 min before the result was visually read. There were 146 samples tested; of these, 51 were from patients with PCM, 11 were from those with histoplasmosis (HP), 15 were from patients with aspergillosis (ASP), 49 were from patients with non-fungal infections (NFI), and 20 of the samples were from normal human serum (HNS). Each of these samples had been previously tested using the immunodiffusion test (ID). Results: From the present study, we obtained $84 \%$ sensitivity and $81 \%$ specificity for the LA test. The 43 serum samples from PCM patients that were positive by the LA test showed agglutination ranging from a score of one plus $(1+$, small clumps with a cloudy background) to four plus (4+, large clumps with a clear background). The titers were maintained to a dilution of 1:64. The samples from the HP (3/1 1), ASP (4/15), and NFI (1 1/49) patients demonstrated cross-reactivity that was not greater than 1 in 4, and no reactivity was observed in the samples of HNS. Conclusion: Due to the straightforward and rapid execution of this LA test, these results should have a significant impact on the development of improved diagnostic methods. Moreover, and although the number of samples examined was small, we conclude that the LA test could serve as a future serodiagnostic method. Nevertheless, a characterization of the interfering factors and the elimination of any cross-reactivity are required prior to its application in routine laboratory analysis.

Keywords: Paracoccidioidomycosis; Serologic test; Latex Agglutination Test.

Financial support: CAPES (Master's scholarship) and CNPq (Edital MCT/CNPq 15/2007-Universal, process $\mathrm{n}$. 471 106/2007-0). 